\title{
Suppliers' network analysis under the perspective of structural, relational and cognitive embeddedness: an exploratory study
}

\author{
Guilherme Rotta Capioto $^{\mathrm{a}}$ (D), Danilo Hisano Barbosa** (D), Juliana Sayuri Kurumoto ${ }^{\mathrm{a}}$ (D), \\ Syntia Lemos Cotrima \\ aUniversidade Estadual de Maringá, Departamento de Engenharia de Produção, Maringá, PR, Brasil \\ dhbarbosa@uem.br
}

\begin{abstract}
Paper aims: To analyze and characterize a supplier network under the analytical perspective of structural, relational and cognitive embeddedness.

Originality: Analysis of a network of suppliers in a soft drink industry using Social Network Analysis (SNA) techniques.

Research method: The case study was used as a research strategy. The analysis of structural perspectives, relational and cognitive embeddedness and their respective variables were considered, as well as measures of centrality and density of the network of suppliers.

Main findings: The analysis allowed to establish the characteristics of the network of suppliers regarding structural, relational and cognitive embeddedness and their respective variables. However, it should be noted that the manuscript addresses a single case study, and it is not possible to generalize the results obtained.

Implications for theory and practice: The findings of this paper can be used as a basis to understand how to use the main metrics of social network analysis to investigate the structural, relational and cognitive characteristics of a company and your network.
\end{abstract}

Keywords

Enterprise networks. Supplier management. Embeddedness.

How to cite this article: Capioto, G. R., Barbosa, D. H., Kurumoto, J. S., \& Cotrim, S. L. (2019). Suppliers' network analysis under the perspective of structural, relational and cognitive embeddedness: an exploratory study. Production, 29, e20180041. https://doi.org/10.1590/0103-6513.20180041

Received: June. 04, 2018; Accepted: Jan. 30, 2019.

\section{Introduction}

In organizational research, the concept of networking began to be discussed in the 1930s, with concepts linked to founding disciplines and conceptual origins, such as sociology, anthropology, and graph theoretic mathematics (Parkhe et al., 2006; Kirchherr, 1992). In recent years, studies focusing on networks and relationships among individuals, groups, and organizations have increased significantly (Hoang \& Antoncic, 2003). Networks not only influence individuals, but also influence how organizations are managed, developed, maintained, and sustained (Nelson, 2001).

In addition, the structure of a network allows companies to more critically analyze their suppliers, increasing the quality of the products and services provided, due to the access of new knowledge (Tsai, 2001). Among the positive effects of strategic supplier, selection is the increase in the manufacturer's competitive advantage (Koufteros et al., 2012). 
In this perspective, network theory has modified not only the way organizations operate within the market, but also the way they see themselves, since many have gone from an individualist view to a systemic view (Silva \& Heber, 2013).

The question of how social relations affects economic action and organizations is one of the classic approaches in social theory (Granovetter, 1985). The notion that business-to-business transactions are embedded in a broader social context has become a recurrent concept for economic and organizational scholars (Borgatti \& Foster, 2003). As is the case of Uzzi (1996) who through the empirical research of embeddedness focused has centered on a wide range of topics, such as business survival (Uzzi, 1996), price fixing (Baker \& Faulkner, 1993), trust and opportunism in interorganizational relations (Batenburg et al., 2003), the social identity of firms (Rao et al., 2000), and the business behavior (Simsek et al., 2003).

The argument of social immersion thus, emphasizes the concrete role of personal relationships and the structures (or networks) of such relationships in generating trust in economic actions (Vasconcelos \& Oliveira, 2012). The first type of relationship is called relational embeddedness and the second is structural embeddedness. There are other types of embeddedness cited in the literature, such as cognitive, which refers to the ability of two organizations to integrate effectively their respective knowledge (Gobbo, 2010).

The structural positioning of the actors in a network of relations is one of the primordial elements to understand the structure of exchange between the actors. In the centrality, for example, an actor centralizes the relationship with other actors of the network, being able to have access to resources, power and information (Sacomano Neto \& Truzzi, 2009).

Another reason justifying the development of this research is the relationship that structural and relational embeddedness has with cognitive embeddedness (Figure 1). Although the interrelationships between the tree dimensions of embeddedness are of great interest among researchers, previous studies tend to focus on the effects of each dimension individually without investigating the relationship between them (Li et al., 2013).

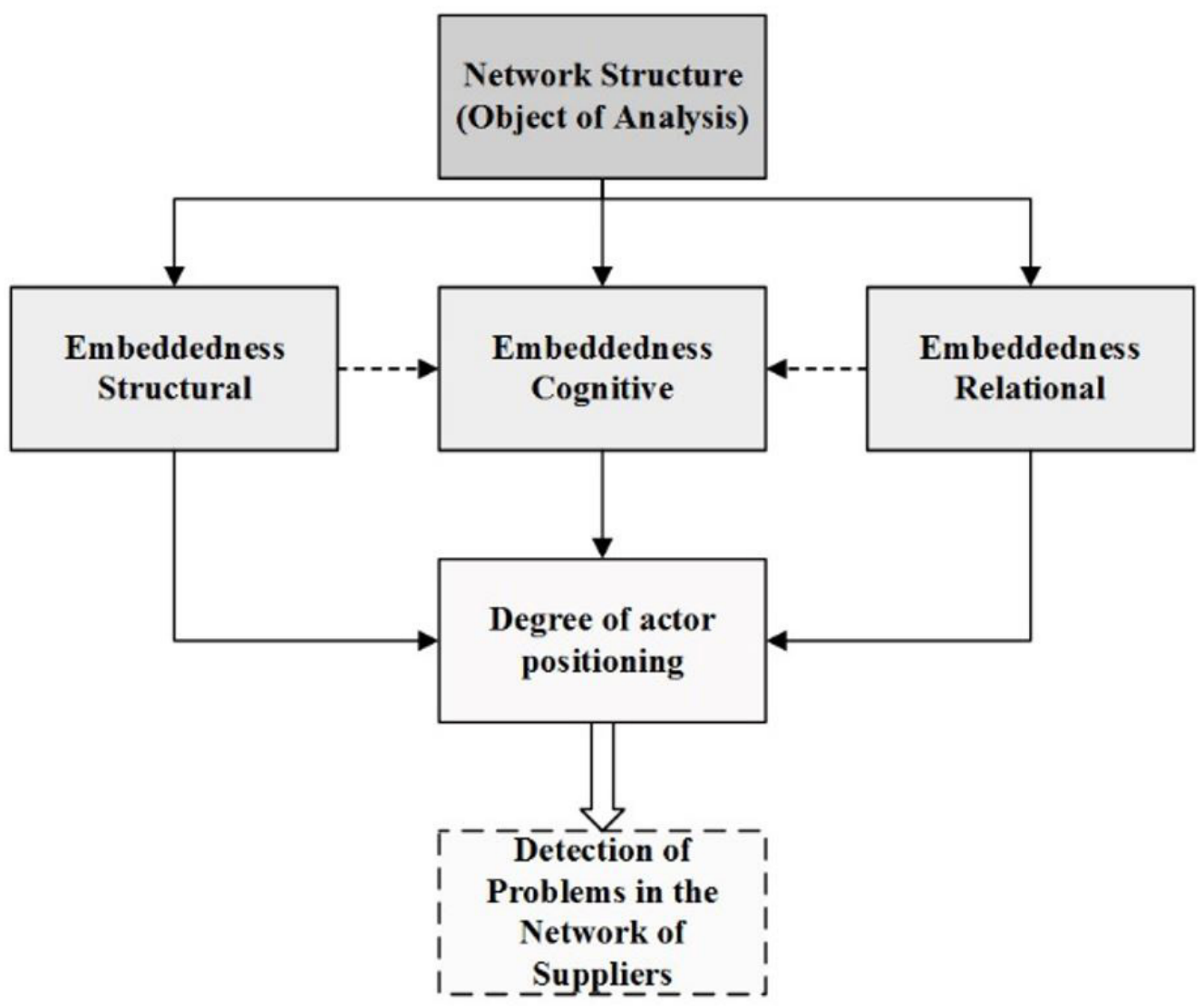

Figure 1. Relationship between embeddedness and actors positioning. Source: Adapted from Gobbo (2010). 
Therefore, the objective of this paper is to analyze and characterize the enterprise network of a soft drink company, under the analytical perspective of structural, relational and cognitive embeddedness. From the positional analysis of the actors present in the network, some problems were identified and some improvements were proposed. The network under analysis was structured with suppliers from the first and second tyer of the Focal Company, by means of a case study.

The choice of a single case project can be justified by the fact that the case selected for analysis is a representative or typical case (Yin, 2001), since the lessons learned from the soft drink company provided a wealth of information on the average experiences of this industry. The network of suppliers of a soft drink industry has a well-defined structure, according to studies such as that of Conceição \& Quintão (2004). The purpose of the choice in this case was to have a consolidated basis to work with an incipient theme, as it was the investigation of the three embeddednesses.

It is valid to highlight that the choice of single case study is strongly related to the adoption of the roster-recall method (Morrison \& Rabellotti, 2009) and by the research involving an ego-centered network. To help map the network and to explore its indicators, the software Gephi 0.9.2, Ucinet 6.357 and Net Draw 2.114 were used.

\section{Literature review}

Enterprise networks can be understood as interorganizational arrangements based on systematic, usually cooperative, links between formally independent firms, which give rise to a particular form of coordination of economic activities (Fusco, 2005). In many business environments, the network presents itself as an important solution to help companies respond quickly to market changes (Hallikas et al., 2004). On the other hand, there are the informal networks and according to Khodabandehloo (2014) the characteristics of these networks for regional development creates vagueness, and might lead to unclear results, in the end affecting the function of the network. In general, informal networks are more prone to personal and formal relationships to issues of control, hierarchy, and authority.

The concept of networks in the organizational sphere has been used in two perspectives: emphasis on its application as an analytical aspect and as a structure of governance (Lopes \& Baldi, 2009). As an analytical perspective, the use of the network allows a contextualized approach of economic action, by which, researchers argue the social immersion in the economy. This inference is supported by the new economic sociology, which has in Granovetter (1985) its theoretical foundation (Swedberg, 2004).

The governance structure refers to the set of tools that coordinate participating organizations seeking to deliver results from the network (Grandori \& Soda, 1995). Studies on this theme are related to the institutional mechanisms by which interorganizational relationships and the attributes of network actors and the form and content of their relationships in a particular institutional context (Oliver \& Ebers, 1998).

\subsection{Suppliers network}

The supply chain is embedded in a complex network of relationships between suppliers, customers and various other stakeholders (Cruz \& Liu, 2011). Thus, vendor selection is increasingly recognized as a critical decision in supply chain management (Millington et al., 2006).

In order to contribute to the management in question, social network theory emphasizes that the economic actions of a supplier are embedded in a network and that its results are substantially influenced by the current pattern of a relationship (Gulati, 1998; Granovetter, 2005). In this sense, the application of techniques on analysis of social networks in supplier's networks are becoming more frequent. Kim et al. (2011) demonstrated how to use social network analysis to investigate the structural characteristics of the supplier's networks, relating the main metrics of social network analysis, considering material flow and contractual relationships. Choi et al. (2001) observed the methodological potential of the SNA and addressed the study of supplier's networks from the perspective of the social network.

Later studies such as Borgatti \& Li (2009) recognized the difficulty of collecting data at the supply network level, but argued that its imperative to manage supplies should be integrated with other management disciplines.

For these authors, a more systematic adoption of SNA is fundamental in the exploration of behavioral mechanisms of the entire supply network and allows us to better understand the operations of these networks, identifying how important are the companies individually considering their positions in the network and how the structural aspects affect the performance of individual companies. 


\subsection{Network properties}

According to Castells (2003), network is a set of interconnected nodes, with several structural properties that can be exploited (Sacomano Neto \& Truzzi, 2009). For Kilduff \& Tsai (2007) these properties are centrality, structural equivalence, structural autonomy, density, cohesion, among others.

Network centrality defines the position of an actor within it, which means to what extent the focal actor occupies a strategic position in the network as a result of being involved with several significant links (Wasserman \& Faust, 1994). For Mote (2005), the centrality can be determined by the number of connections established in each node, being calculated from Equation 1, described in Freeman (1979).

In structural autonomy, an actor mediates the relationship between other two, generating the same results of the centralized structure, such as: access to information, power, resources, status, among other aspects (Sacomano Neto \& Truzzi, 2009). Gobbo (2010) brings this same approach, however highlights that the actor can occupy a structural hole between two other actors with whom he is connected. Burt (1992) understands that structural holes are areas within the network in which loops do not exist or the density is low.

The structural equivalence in turn, at the analysis level, concerns two actors who occupy similar positions in the network structure, a fact that generates similar actions among them (Sacomano Neto \& Truzzi, 2009).

Density is the global level of connections between the members of the network (Provan et al., 2007), and cohesion is the intensity of the relationship (strong or weak), in which the effects are related to the gain of information, knowledge tacit, social control and reciprocity (Sacomano Neto \& Truzzi, 2009). In quantitative terms, the density of a network can be estimated according to Equation 1 (Wasserman \& Faust, 1994).

$$
\mathrm{D}=\frac{2 \mathrm{~T}}{\mathrm{n}(\mathrm{n}-1)}
$$

The network, object of study of this research, has input and output connectivity. In Equation 1, T indicates the number of ties in the network and $n$ the number of nodes.

Cohesion is related to the intensity of the relationship, in which the effects are related to the gain of information, knowledge tacit, social control and reciprocity (Sacomano Neto \& Truzzi, 2009). It concerns the volume of contacts established between the actors. The high volumes and high quality of information exchanged imply the high frequency of interaction and possibly greater cohesion relationship (Fusco, 2005).

\subsection{Positional network analysis - embeddedness}

Polanyi (1944) is known as the creator of the term social immersion (embeddedness). Granovetter (1985), when retaking the concept of Polanyi (1944), directs its focus to the research of the institution of the market, its actors and contexts. Although the researchers have conceptualized embeddedness in different ways, Kim (2014) reiterates the context of the supply chain and defines embeddedness as the extent to which a company relies on a network of supplies, and perceive the influence of it. In this scenario, the expression embeddedness denotes the state of dependency of a company on its suppliers and customers within a specific supply network structure (Choi \& Kim, 2008).

The works of Granovetter (1992) have still generated countless developments. Some authors have sought to identify the various possible types of embeddedness, such as Hess (2004), who identified three types (social, network and territorial); Halinen \& Törnroos (1998), who identified the presence of six different types of embeddedness (social, technological, market, political, temporal and spatial).

Zukin \& DiMaggio (1994) sought to broaden the original concept by incorporating new dimensions such as cognitive, cultural and political dimensions. Recent researches characterize networks based on three types of embeddedness: structural, relational and cognitive (Lechner et al., 2010).

\subsubsection{Structural embeddedness}

Structural embeddedness describes the general architecture of the network, encompassing the properties of links between companies as a whole (Dacin et al., 1999), and emphasizing the informative role of the position that an organization occupies in the general structure of the network (Gulati,1998). Among the important facets of structural incorporation is the presence or absence of links between actors. The variables of this concept include closure, density, connectivity and hierarchy (Wasserman \& Faust, 1994). 
The research on structural embeddedness focuses mainly on the impact of network density and network position on external and performance corporate activities (Gonzalez et al., 2014). Yang et al. (2011) argue that a strategic position in the network ensures non-redundant information and makes the company have bargaining power, formalizing alliances with its partners.

The dense network refers to an effective governance mechanism with a high level of interconnections and shared routines (Rowley et al., 2000). Dense network participants are strongly connected to each other and have many common contacts, developing intense communication and sharing redundant information, often obtained from multiple sources (Polidoro Junior et al., 2011).

In contrast, diffuse network participants have few common contacts and seek to increase the efficiency of information flow (Burt, 1992). Briefly, the degree to which firms benefit from structural embeddedness depends on the centrality and reach of the network (Van Eck et al., 2011). This research was based on Gobbo Junior \& Vasconcellos (2008), which delimit some variables of structural embeddedness, as presented in Table 1.

Table 1. Structural embeddedness variables.

\begin{tabular}{|c|c|c|c|}
\hline $\begin{array}{c}\text { Types of } \\
\text { Embeddedness }\end{array}$ & Variables & Concepts & Authors \\
\hline \multirow{8}{*}{$\begin{array}{l}\text { Structural } \\
\text { Embeddedness }\end{array}$} & Centrality Degree & $\begin{array}{l}\text { It indicates the intensity in which one company is connected } \\
\text { to the others. The degree of a vertex } v \text { (a network point), is the } \\
\text { number of edges incident on } \mathrm{v} \text {, that is, the number of neighbors } \\
\text { of } \mathrm{v} \text {, and is denoted by } \mathrm{d} v \text {. The average degree of the network } \\
\text { modeling graph can be denoted by } \mathrm{dG} \text {, according to Equation } 2 \\
d G=\sum_{i=1}^{n} d G(v i) / n\end{array}$ & $\begin{array}{l}\text { (Balestrin \& Verschoore, } \\
\text { 2016; Cerqueira et al., 2014 }\end{array}$ \\
\hline & $\begin{array}{l}\text { Closeness } \\
\text { Centrality }\end{array}$ & $\begin{array}{l}\text { 1t is related to the proximity or distance of an actor in relation } \\
\text { to other actors in a network (sum of geodesic distances). } \\
\text { The calculation of a vertex proximity is done by the ratio of } \\
\text { the total number of other vertices ( } n-1) \text { by the sum of all the } \\
\text { distances between that vertex and each of the other vertices, as } \\
\text { can be seen in Equation 3: }\end{array}$ & \multirow[t]{2}{*}{ (Borges \& Mourão, 2013) } \\
\hline & & $C c(v)=n-1 / \sum t \in V \backslash v d G(v, t)$ & \\
\hline & \multirow[t]{2}{*}{$\begin{array}{l}\text { Betweenness } \\
\text { Centrality }\end{array}$} & $\begin{array}{l}\text { The equation representing the centrality of a node is related to } \\
\text { the quotient of the shortest number of paths between nodes } \\
\text { in a network, which includes the node in question and also the } \\
\text { number of all the short paths of this network. Equation } 4 \text { : }\end{array}$ & \multirow[t]{2}{*}{$\begin{array}{l}\text { (Borges \& Mourão, 2013; } \\
\text { Cerqueira et al., 2014) }\end{array}$} \\
\hline & & $\begin{array}{l}\operatorname{Bet}(v)=\sum i \neq j \neq v, i \neq v \frac{\sigma i, j(v)}{\sigma i, j} \\
\text { where: } \\
\sigma i, j \text { is the number of geodetic paths that connect the vertices } i \\
\text { and } \mathrm{j} ; \\
\sigma \mathrm{i}, \mathrm{v}(\mathrm{v}) \text { represents the number of geodetic paths that connect the } \\
\text { vertices } \mathrm{i} \text { and } \mathrm{j} \text { through } \mathrm{v} \text {. }\end{array}$ & \\
\hline & Density & $\begin{array}{l}\text { Proportion of the ties in a network divided by the possible } \\
\text { number of ties that could be sent and received. } \\
\text { The density of a network can be calculated according to } \\
\text { Equation } 1 \text { presented in section } 2.1 \text {. }\end{array}$ & (Johnson, 2010) \\
\hline & Stability & Frequency of entry and exit of actors in the network. & $\begin{array}{l}\text { (Gobbo Junior \& } \\
\text { Vasconcellos, 2008) }\end{array}$ \\
\hline & Size & Corresponds to the number of actors in the network. & (Sluzki, 1997) \\
\hline
\end{tabular}

\subsubsection{Relational embeddedness}

The researchers conceptualized relational embeddedness from three perspectives: a direct bond, an asset, and the strength of an interaction (Kim, 2014). The first perspective considers relational incorporation as a direct cohesive link between two companies, also known as a cohesive social interaction and a personal relationship (Lin et al., 2009). In the second perspective, relational chaining is seen as an asset, being a form of trust, reciprocity and obligation, which is rooted in a relationship and is created through ongoing interactions (Tsai \& Ghoshal, 1998). The third perspective highlights the strength aspect of incorporation: relational incorporation is seen as the strength or quality of a relationship (Dhanaraj et al., 2004). 
Relational embeddedness also highlights the strength of ties (Tiwana, 2008). The strong tie refers to the degree of frequency of one company interacting with another and circulating knowledge and resources efficiently, while the weak link is characterized by a freely coupled relationship or the relative frequency of interaction (Choi \& Kim, 2008).

A high degree of relational embeddedness promotes close observations and interactions, allowing companies to access specific information (Khoja et al., 2010). In addition, it is possible to point out other gains based on relational embeddedness, such as the improvement of understanding of partners' needs (Cheung et al., 2010).

Therefore, one of the ways to understand relational embeddedness is through the cohesion of the relations between the actors, and can be understood through the intensity (frequency) of the relationship.

\subsubsection{Cognitive embeddedness}

Cognitive embeddedness, in turn, refers to similarities in representations, interpretations and systems of meaning between enterprises (Nahapiet \& Ghoshal, 1998), or to common contexts among different social actors in a network (Rost, 2011). This dimension involves concepts of shared norms, systems of meanings and values, and can directly affect the development of social capital and organizational relationships (Muniady et al., 2015).

Relationships developed with shared norms and values may be stronger (Moran, 2005). Weick (1995) stated that when there is convergence in goals and values and when interpretations are shared between organizational partners, cognitive capital becomes continuous, cumulatively favorable. The cognitive dimension reflects the concept that distinct networks develop unique terms, acronyms, and number interpretations.

To determine the potential of cognitive variety present in a network, it is necessary to analyze the density of loops. A large number of present loops, as a percentage of the total possible number (dense network), indicates the possibility of access to different types of knowledge possessed by other actors (Gilsing \& Duysters, 2008).

Therefore, two variables related to embeddedness cognitive can be highlighted. The first is the absorptive capacity, which is the organizational ability to recognize the value of new and external information, to assimilate it, and to apply for commercial purposes (Cohen \& Levinthal, 1990) and the congnitive distance, which refers to the difference between individuals with cognitively different frameworks in a network (Gilsing \& Duysters, 2008).

Nahapiet \& Ghoshal (1998) studied the interactions between the three dimensions of embeddedness and suggested that even when these dimensions are analytically separated, they still have highly interrelated elements. Consequently, the relational and cognitive aspect should affect the structural, resulting in dynamic interrelationships.

\section{Materials and methods}

Exploratory studies are performed when the objective is to examine a subject or a research problem that is not well studied (Gil, 2008). In general, exploratory research involves a bibliographical survey, interviews with people who have had practical experiences with the problem researched and analysis of examples that stimulate understanding (Prodanov \& Freitas, 2013).

As for technical procedures, a case study is an (research that investigates- changes) a contemporary phenomenon within its real-life context, particularly when the boundaries between phenomena and context are not clearly defined (Yin, 2001). The researcher does not intend to intervene on the object to be studied, but to reveal it as he perceives it (Fonseca, 2002).

The choice of single case study is directly related to two determining situations. The first is due to the adoption of the roster-recall method (Morrison \& Rabellotti, 2009). The roster-recall method (Morrison \& Rabellotti, 2009), which consists of providing a list of all the members to each actor in the network, was used so that he can mention with which he has relationship. The second justification is that the analysis involves an ego-centered network.

Another choice was the use of non-directed networks, since the applied questions referred to the contractual relationship and not following the flow of materials, as in the case of directed networks, where the geodesics from ni (origin) to nj (destination) may not be the same as those from nj to ni.

The authors followed the methodological assumptions of Yin (2001) and Miguel (2007) for the development of the case study. In the first stage, it was the theory development, in which it was sought to know the literature of networks that in turn helped in the work delimitation and in the identification of the variables to be analyzed. Shortly thereafter, the case planning was carried out, defining the following protocol presented in Table 2. 
Table 2. Case study protocol.

\begin{tabular}{ll}
\hline Research Question & How is the supplier's network of a soft drink company characterized under the analytical cut of \\
structural, relational and cognitive embeddedness? \\
Unit of analysis & Structural, relational and cognitive embeddedness of an ego-centered network. \\
Organization & Soft drink Factory \\
Time Limit & 2016 and 2017 \\
& Interviews, direct observations and secondary sources (database of company suppliers, \\
Data Sources and Reliability & publications and reports related to the área). \\
& Multiple sources of evidence (direct observation, interviews and documents) \\
Validity of constructs & Validation of responses by respondents \\
Internal validity & Triangulation of data sources and compliance with the standard \\
External aalidity & Use of theory in a single case study \\
& What are the top tier company's suppliers? \\
& Are these suppliers involved in advanced collaborative practices such as R \& D partnerships? \\
& How is the relationship between the company and suppliers related to the structural, relational \\
Examples of key issues & and cognitive variables of a supplier's network characterized? \\
& How is the relationship between first and second tier suppliers? ls there a contractual \\
& relationship or just business relationships? \\
\hline
\end{tabular}

Source: Adapted from Yin (2001).

With the protocol elaborated the third stage was carried out, which consists of a pilot test applied with the soft drink company, denominated Focal Company. The test allowed checking the data quality and making the necessary adjustments. The fourth step, data collection, was performed at the Focal Company.

The Focal Company was founded in the 1950s and since then has been expanding its brand. It currently employs more than 80 employees and produces just over 6 million liters per year of soft drinks, bottled in PET or glass bottles of different sizes. The Focal Company, all its suppliers of raw material for the production of soft drinks in PET bottles (first tier suppliers) and the main second tier suppliers were considered as objects of analysis for this study.

The empirical study was based on three semi-structured interviews conducted in loco with the general manager of the soft drink factory.

All data collected were completed from direct observations and secondary sources (publications and reports related to the area of this research and databases). The use of secondary sources improves the validity of all data obtained (Yin, 2001). To fill the matrix, the scale (weight) used in the Focal Company's relations with its first tier suppliers had as criteria the years of partnership, being: grade 1 (up to 2 years of partnership); grade 2 (from 2 to 5 years of partnership); and grade 3 (more than 5 years of partnership). The scale used in the relations of the first tier companies with their respective suppliers (second layer companies) was defined as: grade 1 (common raw material supplier); grade 3 (strategic product provider).

Then, the techniques of Social Network Analysis (SNA) and Ucinet software 6.357 and NetDraw 2.114 (Borgatti et al., 2002) were used to reproduce the quantitative indicators. In this sense, the network was quantitatively analyzed according to three centrality indicators indicated in Table 1 . Subsequently, in a qualitative way, the network was characterized under the analytical cut of structural, relational and cognitive embeddedness. Finally, through observations on the positioning of the actors in the network, the main problems were listed, and with some references, some improvements were suggested.

Figure 2 depicts the procedures that were followed in the development of this work, in order to achieve the established objectives.

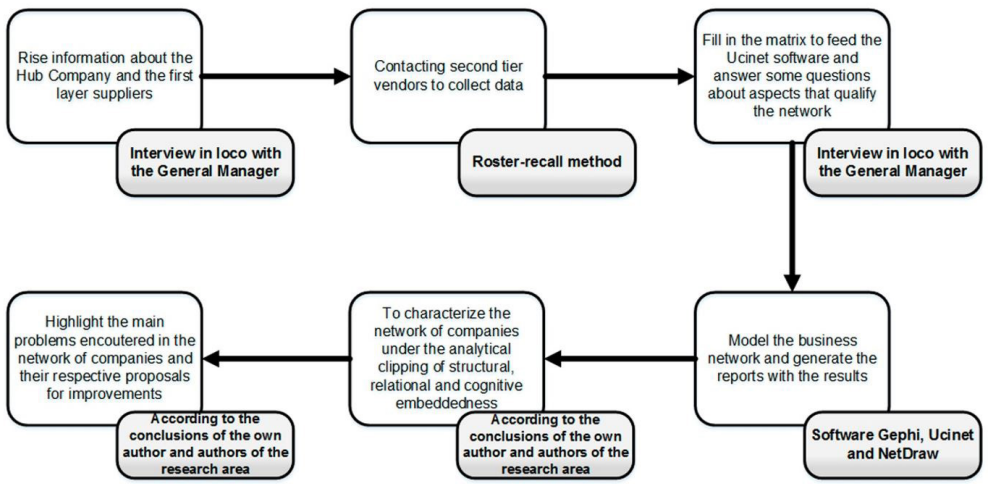

Figure 2. Sequencing of the steps performed in this research. 


\section{Results and discussion}

This section aims to describe and analyze the set of data obtained from the network mapping of suppliers of the soft drink factory.

\subsection{Characterization of the supplier network}

This research presents an example of application in a network of companies of a soft-drink factory. In order to better characterize the network, Figure 3 is divided into business segments, where the companies supplying both raw material and packaging for the company's soft drink production are presented.

The suppliers of raw material are consolidated in the market, most of them being large national or multinational companies. Few companies serve only a certain region. In supremacy, they are leading and pioneering organizations in the segment in which they operate, recognized for the quality of their products and for cooperation with their customers. Figure 4 shows the enterprise network.
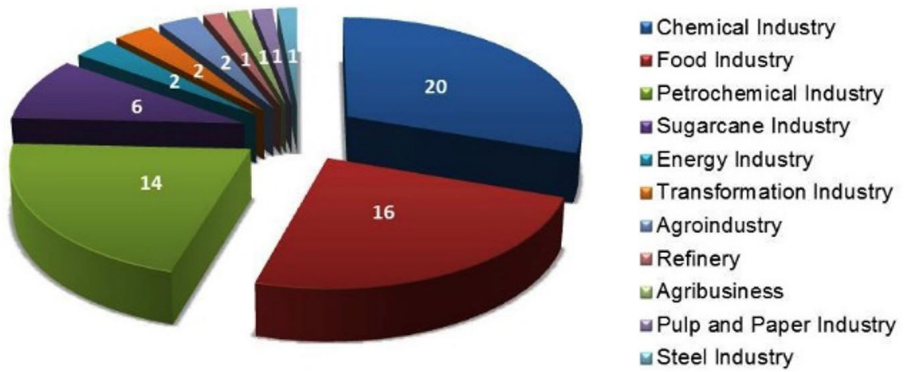

Figure 3. Companies segments in the network.

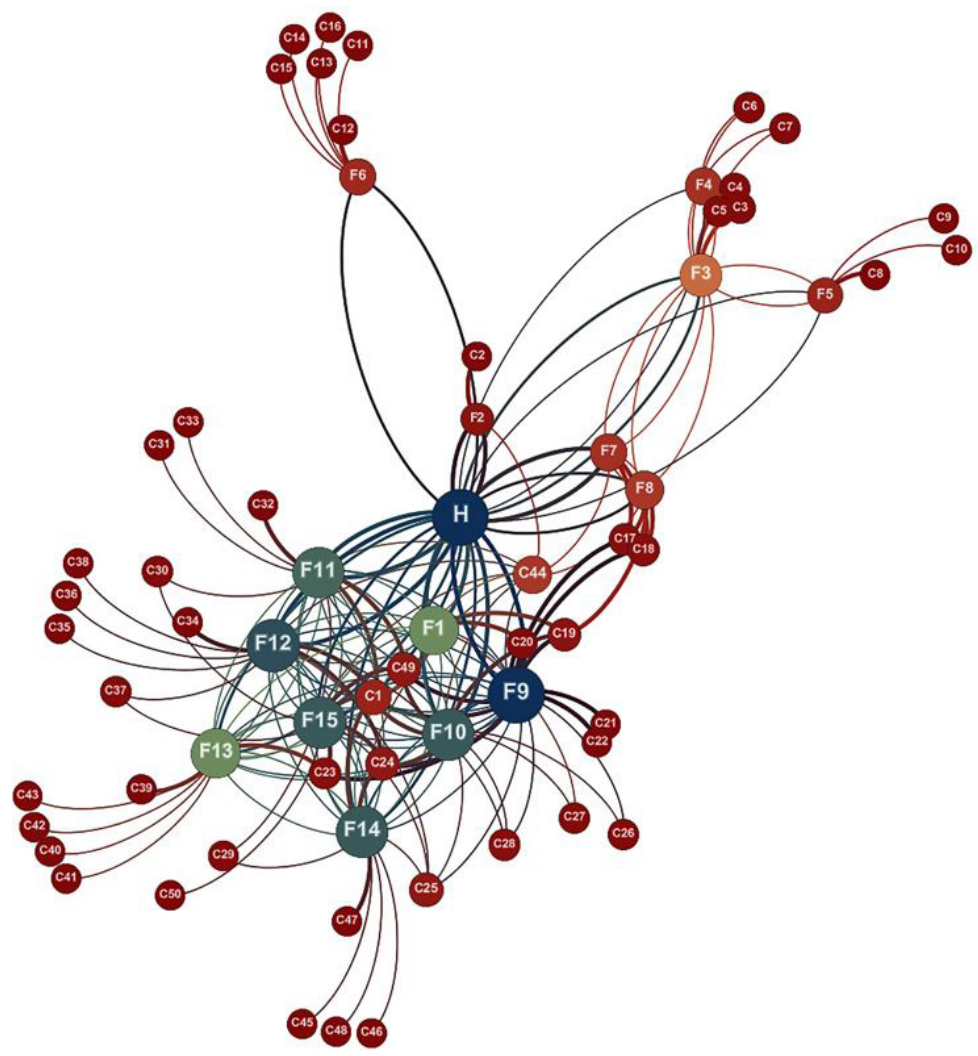

Figure 4. Enterprise network. 
The Focal Company was designated as actor $\mathrm{H}$ (Figure 4). The first and second tier suppliers were represented as actors $\mathrm{F}$ and $\mathrm{C}$, respectively. The size of the sphere, varied according to the degree of centrality of each actor. With respect to the edges (lines that connect the knots), the thickness varied according to the weight assigned to each relation (the larger the weight, the greater the line thickness).

Figure 4 shows the clear representativeness of F1, F2, F7, F9, F10, F11, F12, suppliers in which the focal company has partnered for more than 5 years. F3, F6 and F8, F13, F14, F15, companies with a partnership varying between 3 and 5 years with company H. Firstly, F1 is a supplier of sugar, an indispensable raw material not only in the production of soft drinks, but also in several other products, which explains the various F1 connections in the network.

The companies F9, F10, F11 and F12 are responsible for supplying the products that will give the soft-drinks its characteristic flavor, such as: aromas, conservatives, juices, emulsion, grape preparation, pineapple preparation and guarana extract. These companies share information with each other and maintain contact with several other second tier suppliers.

The companies F13, F14 and F15 provide chemical inputs (citric acid, ascorbic acid, sodium benzoate and caramel dye) and their high importance in the network is associated with the strategic product that is commercialized, and it can be produced with formulation exclusively for each client. In turn, the second layer companies $\mathrm{C} 1$ and $\mathrm{C} 44$ are also highlighted in the network (Figure 4) by the highest level of centrality (Table 3), due to the good service provided and the efficient logistics, seeking to streamline and optimize processes of movement of between the companies' partners. Although the graphical analysis is important, then the quantitative results will be presented for a further deepening of this analysis.

Table 3. Structural measures.

\begin{tabular}{|c|c|c|c|c|c|c|c|c|c|c|c|c|}
\hline \multirow{2}{*}{ Category } & \multicolumn{4}{|c|}{ Centrality Degree } & \multicolumn{4}{|c|}{ Closeness Centrality } & \multicolumn{4}{|c|}{ Betweenness Centrality } \\
\hline & Node & Value & Node & Value & Node & Value & Node & Value & Node & Value & Node & Value \\
\hline $\begin{array}{l}\text { Main } \\
\text { Actor }\end{array}$ & F9 & 33.846 & & & $\mathrm{H}$ & 56.522 & & & $\mathrm{H}$ & 46.585 & & \\
\hline \multirow{4}{*}{1} & $\mathrm{H}$ & 23.077 & $\mathrm{~F} 12$ & 27.692 & F9 & 52.846 & \multirow{2}{*}{ F14 } & \multirow{2}{*}{50.781} & F6 & 17.740 & \multirow{2}{*}{ F13 } & \multirow{2}{*}{15.529} \\
\hline & $\mathrm{F} 1$ & 21.538 & F13 & 21.538 & F10 & 50.781 & & & F9 & 16.886 & & \\
\hline & F10 & 26.154 & F14 & 26.154 & $\mathrm{~F} 11$ & 50.388 & \multirow{2}{*}{ F15 } & \multirow{2}{*}{50.781} & F11 & 12.423 & \multirow{2}{*}{ F14 } & \multirow{2}{*}{14.362} \\
\hline & F11 & 26.615 & F15 & 26.154 & F12 & 51.181 & & & F12 & 15.104 & & \\
\hline \multirow{3}{*}{11} & F3 & 15.385 & F8 & 10.769 & $\mathrm{~F} 1$ & 49.618 & F13 & 49.618 & F3 & 9.151 & $\mathrm{~F} 10$ & 5.806 \\
\hline & $\mathrm{F} 4$ & 10.769 & $\mathrm{C} 1$ & 10.769 & \multirow{2}{*}{ F3 } & \multirow{2}{*}{41.139} & \multirow{2}{*}{$\mathrm{C} 44$} & \multirow{2}{*}{43.046} & F4 & 6.130 & \multirow{2}{*}{ F15 } & \multirow{2}{*}{8.157} \\
\hline & F6 & 10.769 & $\mathrm{C} 44$ & 15.385 & & & & & F5 & 9.087 & & \\
\hline \multirow{20}{*}{111} & \multirow[t]{5}{*}{$\mathrm{F} 2$} & \multirow[t]{5}{*}{4.615} & \multirow[t]{5}{*}{$\mathrm{C} 24$} & \multirow[t]{5}{*}{7.692} & $\mathrm{~F} 2$ & 34.143 & C30 & 34.759 & \multirow[t]{5}{*}{$\mathrm{F} 1$} & 4.014 & \multirow[t]{5}{*}{ F8 } & \multirow[t]{5}{*}{1.685} \\
\hline & & & & & $\mathrm{F} 4$ & 38.690 & C31 & 33.679 & & & & \\
\hline & & & & & F5 & 38.922 & $\mathrm{C} 32$ & 33.679 & & & & \\
\hline & & & & & F6 & 38.922 & $\mathrm{C} 33$ & 33.679 & & & & \\
\hline & & & & & F7 & 39.394 & C34 & 34.031 & & & & \\
\hline & F5 & 7.692 & C25 & 7.692 & F8 & 39.634 & C35 & 34.031 & F2 & 3.135 & & \\
\hline & & & & & $\mathrm{C} 1$ & 39.394 & C36 & 34.031 & & & & \\
\hline & & & & & $\mathrm{C} 17$ & 36.723 & C37 & 34.946 & & & & \\
\hline & & & & & C18 & 36.723 & C38 & 34.031 & & & & \\
\hline & & & & & C19 & 37.143 & C39 & 33.333 & & & & \\
\hline & F7 & 9.231 & & & $\mathrm{C} 20$ & 35.135 & $\mathrm{C} 40$ & 33.333 & & & C44 & 3.179 \\
\hline & & & & & $\mathrm{C} 21$ & 34.759 & $\mathrm{C} 41$ & 33.333 & & & & \\
\hline & & & & & $\mathrm{C} 22$ & 34.759 & $\mathrm{C} 42$ & 33.333 & & & & \\
\hline & & & & & $\mathrm{C} 23$ & 36.723 & $\mathrm{C} 43$ & 33.333 & & & & \\
\hline & & & & & $\mathrm{C} 24$ & 38.235 & C45 & 33.854 & & & & \\
\hline & C19 & 6.154 & C49 & 7.692 & $\mathrm{C} 25$ & 38.235 & C46 & 33.854 & F7 & 1.072 & & \\
\hline & & & & & C26 & 35.135 & $\mathrm{C} 47$ & 33.854 & & & & \\
\hline & & & & & $\mathrm{C} 27$ & 34.211 & $\mathrm{C} 48$ & 33.854 & & & & \\
\hline & & & & & $\mathrm{C} 28$ & 36.313 & C49 & 37.143 & & & & \\
\hline & & & & & $\mathrm{C} 29$ & 34.946 & C50 & 33.854 & & & & \\
\hline
\end{tabular}


Table 3. Continued...

\begin{tabular}{|c|c|c|c|c|c|c|c|c|c|c|c|c|}
\hline \multirow{2}{*}{ Category } & \multicolumn{4}{|c|}{ Centrality Degree } & \multicolumn{4}{|c|}{ Closeness Centrality } & \multicolumn{4}{|c|}{ Betweenness Centrality } \\
\hline & Node & Value & Node & Value & Node & Value & Node & Value & Node & Value & Node & Value \\
\hline \multirow{26}{*}{ IV } & $\mathrm{C} 2$ & 1.538 & $\mathrm{C} 27$ & 3.077 & $\mathrm{C} 2$ & 27.197 & $\mathrm{C} 10$ & 29.139 & $\mathrm{C} 1$ & 0.000 & $\mathrm{C} 27$ & 0.000 \\
\hline & C3 & 3.077 & $\mathrm{C} 28$ & 4.615 & & & & & $\mathrm{C} 2$ & 0.000 & $\mathrm{C} 28$ & 0.000 \\
\hline & C4 & 3.077 & $\mathrm{C} 29$ & 3.077 & & & & & $\mathrm{C} 3$ & 0.000 & $\mathrm{C} 29$ & 0.000 \\
\hline & $\mathrm{C} 5$ & 3.077 & $\mathrm{C} 30$ & 3.077 & $\mathrm{C} 3$ & 29.412 & C11 & 29.139 & C4 & 0.000 & C30 & 0.000 \\
\hline & C6 & 3.077 & C31 & 1.538 & & & & & C5 & 0.000 & C31 & 0.000 \\
\hline & $\mathrm{C} 7$ & 3.077 & $\mathrm{C} 32$ & 1.538 & & & & & C6 & 0.000 & $\mathrm{C} 32$ & 0.000 \\
\hline & C8 & 1.538 & C33 & 1.538 & C4 & 29.412 & $\mathrm{C} 12$ & 28.139 & C7 & 0.000 & C33 & 0.000 \\
\hline & C9 & 1.538 & C34 & 1.538 & & & & & C8 & 0.000 & C34 & 0.000 \\
\hline & $\mathrm{C} 10$ & 1.538 & C35 & 1.538 & & & & & C9 & 0.000 & C35 & 0.000 \\
\hline & C11 & 1.538 & C36 & 1.538 & C5 & 29.412 & $\mathrm{C} 13$ & 28.139 & $\mathrm{C} 10$ & 0.000 & C36 & 0.000 \\
\hline & $\mathrm{C} 12$ & 1.538 & C37 & 3.077 & & & & & C11 & 0.000 & C37 & 0.000 \\
\hline & C13 & 1.538 & C38 & 1.538 & & & & & $\mathrm{C} 12$ & 0.000 & C38 & 0.000 \\
\hline & C14 & 1.538 & C39 & 1.538 & C6 & 29.412 & C14 & 28.139 & $\mathrm{C} 13$ & 0.000 & C39 & 0.000 \\
\hline & $\mathrm{C} 15$ & 1.538 & C40 & 1.538 & & & & & C14 & 0.000 & $\mathrm{C} 40$ & 0.000 \\
\hline & C16 & 1.538 & $\mathrm{C} 41$ & 1.538 & & & & & $\mathrm{C} 15$ & 0.000 & $\mathrm{C} 41$ & 0.000 \\
\hline & $\mathrm{C} 17$ & 4.615 & C42 & 1.538 & C7 & 29.412 & C15 & 28.139 & C16 & 0.000 & C42 & 0.000 \\
\hline & $\mathrm{C} 18$ & 4.615 & C43 & 1.538 & & & & & C17 & 0.144 & $\mathrm{C} 43$ & 0.000 \\
\hline & $\mathrm{C} 20$ & 3.077 & C45 & 1.538 & & & & & C18 & 0.144 & C45 & 0.000 \\
\hline & $\mathrm{C} 21$ & 1.538 & C46 & 1.538 & C8 & 28.139 & & & C19 & 0.148 & C46 & 0.000 \\
\hline & $\mathrm{C} 22$ & 1.538 & C47 & 1.538 & & & & & $\mathrm{C} 20$ & 0.000 & $\mathrm{C} 47$ & 0.000 \\
\hline & $\mathrm{C} 23$ & 4.615 & C48 & 1.538 & & & & & $\mathrm{C} 21$ & 0.000 & C48 & 0.000 \\
\hline & $\mathrm{C} 26$ & 3.077 & C50 & 1.538 & C9 & 28.139 & C16 & 28.139 & C22 & 0.000 & C49 & 0.000 \\
\hline & & & & & & & & & $\mathrm{C} 23$ & 0.000 & C50 & 0.000 \\
\hline & & & & & & & & & $\mathrm{C} 24$ & 0.000 & & \\
\hline & & & & & & & & & $\mathrm{C} 25$ & 0.000 & & \\
\hline & & & & & & & & & C26 & 0.000 & & \\
\hline
\end{tabular}

\subsection{Structural analysis}

The network is made up of sixty-six actors (including the Focal Company). The first level of the supplier layer has fifteen actors. According to Sluzki (1997), small networks are less effective in situations of overload or long-term stress, since members begin to avoid contact to avoid overload or, on the contrary, tend to overload. For the author, numerous networks run the risk of being ineffective, since there will always be a chance that other individuals will already be taking care of the same problem.

After completing the relations matrix in Ucinet 6.357, the data were imported into NetDraw 2.114 to generate the results of the centrality indicators. To facilitate the interpretation of the data, the results were divided into categories, grouping of percentages into ranges of values from 0.000 to 100.000 , as shown in Table 3 .

In Table 3, it is possible to notice the existence of three indicators of centrality: centrality degree; closeness centrality and betweenness centrality. By first analyzing the centrality degree, it is verified that the F9 supplier is the one that receives the most and transmits information throughout the network, a fact that can be proven due to the importance and specificity of the product it provides. Its position within the network is strategic, being considered central actor.

As for the degree of closeness centrality, the Focal Company has a higher degree. In fact, by analyzing the network (Figure 4) the actor $\mathrm{H}$ is in a more central position as to the smallest path he has to go to reach the other nodes of the network. This measures their independence from the control of other actors (Pineyrua et al., 2016). According to Michelon (2015), generally, the node with the highest degree of proximity will have better knowledge of the network and greater power of dissemination of information in comparison with the other nodes.

The last indicator of centrality to be observed is the degree of intermediation. It is possible to note that the first-tier providers (and the C44 supplier, second layer) present the highest value. An important factor that a higher degree of intermediation is the comparison of the price of the products between the companies that it intermediates. Using Equation 1 (section 2.2) and taking into account that the network had 66 actors and 195 ties, the density obtained was 9.09\%. In this way, the network is considered diffuse. 
This presupposes the existence of difficulties for the companies to make decisions and to solve problems together (Coleman et al., 1966). According to Sacomano Neto (2004), in the diffuse networks the number of nodes is greater, which harms and lessens the need for supplier development.

\subsection{Relational analysis}

The duration of Focal Company contacts with its first tier suppliers is, for the most part, of long years, as shown in Figure 5.

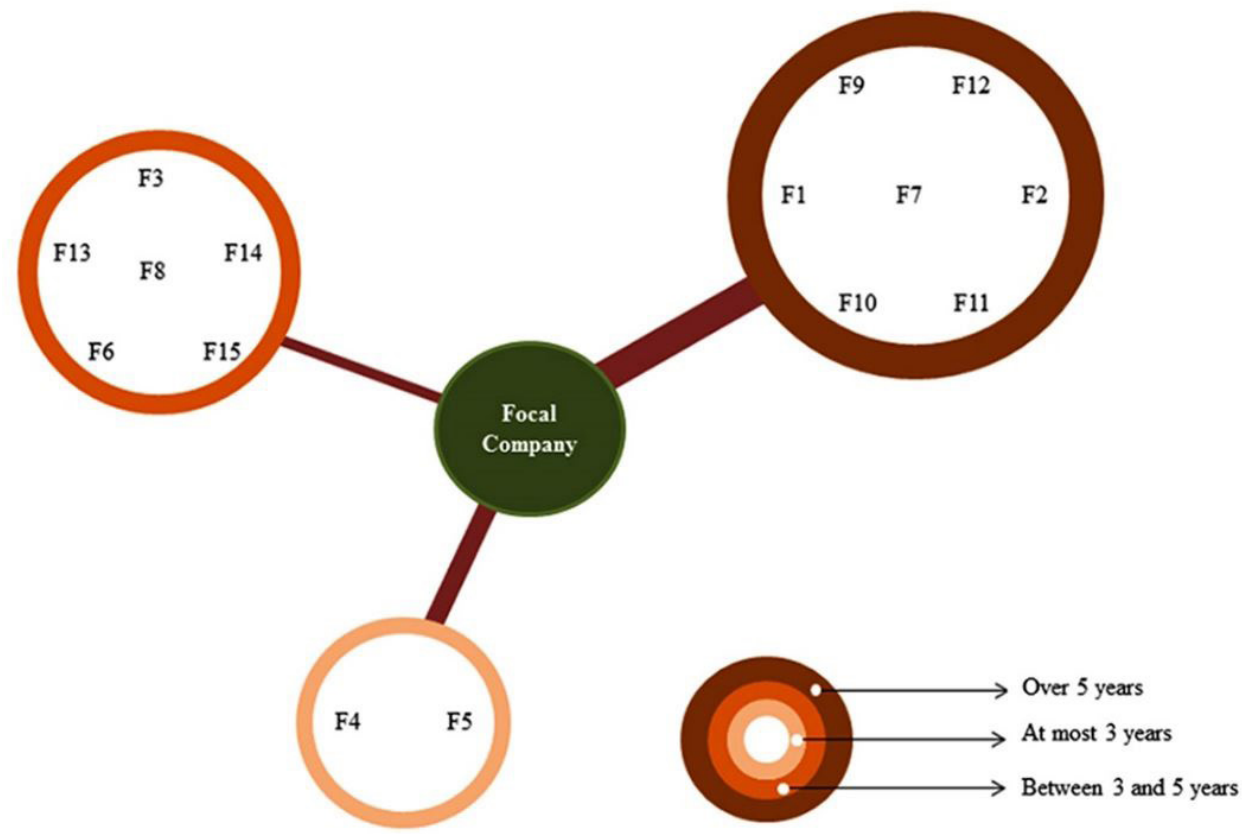

Figure 5. Years of Partnership between the Focal Company and first level suppliers.

The long years of partnership with supplier companies is also a lot due to the time the general manager has been in Focal Company, for more than ten years. In all this time the manager, who is responsible for the purchasing department, maintains an intense contact with the suppliers, in order to intermediate the internal needs of the organization and the external availability of its partners.

In Figure 5, it can also be observed that the supplier's network is cohesive, which according to Sacomano Neto \& Truzzi (2009) can be understood through the intensity of the relationship (strong or weak, long term relationships, among others). As highlighted in section 2.2.2, the strong relationship between firms refers to the degree to which they interact with one another. Therefore, Focal Company maintains strong relationships with several first-tier suppliers, since knowledge and new information circulate efficiently among these companies, in addition to the long period in which they have a commercial agreement, as shown in Figure 5.

\subsection{Cognitive analysis}

The cognitive distance between suppliers F9, F10, F11 and F12 is smaller, because the organizational differences in the know-how, perceptions and skills shared between these companies are smaller (Gobbo Junior \& Vasconcellos, 2008). Consequently, the absorptive capacity between these companies tends to be greater, since the greater the frequency of communication, the new skills are developed and the faster the feedbacks.

In Table 4, the problems regarding the degree of positioning of the actors in the network are presented.

It is noted that many companies still do not have close relationships with their suppliers due to the distrust they have to share managerial and technological knowledge. In contrast, the cognitive variety of the network is low, considering that the network is diffuse (density of 9.09\%). Cognitive embeddedness is also positively 
4. Main Problems ldentified and Proposed Solutions.

\begin{tabular}{|c|c|}
\hline Main Problems Identified & Proposed Solutions \\
\hline $\begin{array}{l}\text { The location of the suppliers is distant. With this, the } \\
\text { contacts usually occur by telephone, not allowing more } \\
\text { detailed information exchange }\end{array}$ & $\begin{array}{l}\text { The use of information technology (1T) helps to bring the company closer to its } \\
\text { suppliers. The goal of 1T is to provide companies with the main input generated } \\
\text { by information technology and then transformed into a subsidy for market actions } \\
\text { (Mckenna, 1992). In the case of marketing, products and services are invented through } \\
\text { collaboration between companies in digital corporate networks (Brum, 2017). }\end{array}$ \\
\hline $\begin{array}{l}\text { Little sharing of information and knowledge among } \\
\text { packaging suppliers }\end{array}$ & $\begin{array}{l}\text { The dissemination of cognitive culture may be the progress toward a system of } \\
\text { collaboration between these companies. Some actions should be taken, such as defining } \\
\text { a radar of external competences, aiming at accessing specialized knowledge with } \\
\text { competitive interest, establishing a structured process based on decision gates } \\
\text { (Marques, 2015). }\end{array}$ \\
\hline $\begin{array}{l}\text { The departmentalization in some supplier companies } \\
\text { creates internal barriers. This prevents them from } \\
\text { getting a clear view of their own processes, not } \\
\text { concentrating efforts on the needs and requirements } \\
\text { of customers }\end{array}$ & $\begin{array}{l}\text { To structure the organization by processes, allowing more autonomy and polyvalence } \\
\text { of the workers so that they can solve problems without having to resort to another } \\
\text { department (flexible organization) (Gonçalves, 2000). }\end{array}$ \\
\hline Lack of indicators for strategic selection of supplies & $\begin{array}{l}\text { It could be used, for example, the model of Handfield et al. (2000). The ultimate } \\
\text { objective of the matrix is to optimize the relationship between costs and risks. } \\
\text { The matrix crosses two dimensions: impact on the financial result and uncertainty of } \\
\text { supply, generating four quadrants for the categorization of commodities }\end{array}$ \\
\hline
\end{tabular}

associated with relational embeddedness. As companies develop a closer agreement, incorporating their beliefs, assumptions, and expectations into the network, reciprocity rules are likely to grow stronger, making actors develop common standards of behavior. These behavioral similarities lead to the development of similar beliefs, that is, cognitive similarities (Simsek et al., 2003).

Most of the problems identified in Table 4 are summarized in the lack of collaboration and cultural differences among companies part of the network. Therefore, it is first necessary to get participants in these alliances to change their minds, and then to adapt to new ways of sharing knowledge. New organizational structures based on knowledge are emerging, among these structures, Galbraith (1997) presents the "Innovative Organization", in which two organizational structures must coexist: operational and innovative; whose purpose is to promote the creation and application of knowledge. It is up to the innovative structure to design ideas and the operational structure to implement them. The feasibility of the suggested proposals should be analyzed by the managers and directors of the factory.

\section{Conclusion}

The present article had as main objective to analyze and to characterize the companies' network of a soft drink factory, under the analytical perspective of the structural, relational and cognitive embeddedness. This paper may contribute to future research providing knowledge, especially about cognitive embeddedness, which is still little explored in the literature. Previous studies have suggested that the structural dimension is the origin of the emergence of relational and cognitive capital (Liao \& Welsch, 2005).

Khodabandehloo (2014) points out that informal networking should be avoided as it is inaccurate and makes it difficult to obtain tangible results. This research differs from the author's opinion and agrees with Jericó et al. (2008) that formal and informal communication are complementary to an organizational diagnosis and more flexible actions.

As for the relationship between embeddedness, it can first be emphasized that cognitive embeddedness is positively associated with relational embeddedness, that is, as companies develop an agreement embodying their convictions, premises and expectations within the network, reciprocity will likely become stronger, causing actors to develop common behavioural patterns. These behavioural similarities lead to the development of similar beliefs, or cognitive similarities

As for the second relationship, that is, structural embeddedness with cognitive, a factor that deserves attention is the question of cognitive distance. It can be affirmed from the results obtained that the cognitive distance is small among companies that maintain strong ties in the network (degree of cohesion), that is, they are constantly learning and innovating their processes through the information and expertise they share. Consequently, the absorptive capacity between these companies is greater, since the greater the frequency of communication, the new skills are developed and the faster the feedbacks. In contrast, the cognitive variety of the network is 
small, considering that the density of loops, another indicator of structural embeddedness, presented a low percentage. In this way, the access to diverse types of knowledge in the network, in a global way, is restricted.

The first limitation found in this study was related to the number of actors present in the second layer, and only the main ones were studied. Another limitation is the type of embeddedness that has not been addressed, such as: social, technological, market, political, temporal and spatial (Halinen \& Törnroos, 1998).

Thus, it is suggested that future research addresses other types of embeddedness, as well as involving a quantitative study to deepen different analysis. Another suggestion is to cover a larger number of actors and to replicate the proposed methodological approach in networks of other economic sectors in order to increase the reliability of the results of this research.

In addition, new case studies using the same methodological approach would help to identify discrepancies between different economic sectors, for example by identifying the downstream character of a network in the service sector, where relational aspects such as the frequency of communication (embeddedness) with their customers would improve absorptive capacity in identifying behavioral changes and consumer market trends.

\section{References}

Baker, W. E., \& Faulkner, R. R. (1993). The social organization of conspiracy: lllegal networks in the heavy electrical equipment industry. American Sociological Review, 58(6), 837-860. http://dx.doi.org/10.2307/2095954.

Balestrin, A., \& Verschoore, J. (2016). Redes de cooperação empresarial: estratégias de gestão na nova economia (2. ed.). Porto Alegre: Bookman.

Batenburg, R. S., Raub, W., \& Snijders, C. C. P. (2003). Contacts and contracts: dyadic embeddedness and the contractual behavior of firms. Research in the Sociology of Organizations, 20, 135-188. http://dx.doi.org/10.1016/S0733-558X(02)20006-3.

Borgatti, S. P., \& Foster, P. C. (2003). The network paradigm in organizational research: a review and typology. Journal of Management, 6(6), 991-1013. http://dx.doi.org/10.1016/S0149-2063(03)00087-4.

Borgatti, S. P., \& Li, X. (2009). On social network analysis in a supply chain context. Journal of Supply Chain Management, 45(2), 5-21. https://doi.org/10.1111/j.1745-493X.2009.03166.X.

Borgatti, S. P., Everett, M. G., \& Freeman, L. C. (2002). Ucinet for windows: software for social network analysis. Harvard: Analytic Technologies.

Borges, L. 0., \& Mourão, L. (2013). O trabalho e as organizações: atuações a partir de psicologia. Porto Alegre: Artmed.

Brum, A. M. (2017). Endomarketing estratégico: como transformar líderes em comunicadores e empregados em seguidores. São Paulo: Integrare.

Burt, R. S. (1992). Structural holes: the social structures of competition. England: Harvard University Press.

Castells, M. (2003). A galáxia da internet: reflexões sobre a internet, os negócios e a sociedade (Trad. Maria Luiza). Rio de Janeiro: Jorge Zahar.

Cerqueira, C. H. Z., Costa, J. M. S., \& Carvalho, D. M. A. (2014). Aplicação de análise de redes sociais em uma cadeia de suprimentos de uma empresa do setor elétrico brasileiro. Sistema \& Gestão, 9(4), 418-429. https://doi.org/10.7177/sg.2014.V9.N4.A1.

Cheung, M. S., Myers, M. B., \& Mentzer, J. T. (2010). Does relationship learning lead to relationship value? A cross-national supply chain investigation. Journal of Operations Management, 28(6), 472-487. http://dx.doi.org/10.1016/j.jom.2010.01.003.

Choi, T. Y., \& Kim, Y. (2008). Structural embeddedness and supplier management: a network perspective. The Journal of Supply Chain Management, 44(4), 5-13. http://dx.doi.org/10.1111/j.1745-493X.2008.00069.x.

Choi, T.Y., Dooley, K.J., \& Rungtusanatham, M. (2001). Supply networks and complex adaptive systems: control versus emergence. Journal of Operations Management, 19(3), 351-366. https://doi.org/10.1016/S0272-6963(00)00068-1.

Cohen, W. M., \& Levinthal, D. (1990). Absorptive capacity: a new perspective on learning and innovation. Administrative Science Quarterly, 35(1), 128-152. http://dx.doi.org/10.2307/2393553.

Coleman, J. S., Katz, E., \& Menzel, H. (1966). Medical innovation: a diffusion study. Indianapolis: Bobbs-Merrill.

Conceição, S. V., \& Quintão, R. T. (2004). Avaliação do desempenho logístico da cadeia brasileira de suprimentos de refrigerantes. Gestão \& Produção, 11(3), 441-453. http://dx.doi.org/10.1590/S0104-530X2004000300015.

Cruz, J. M., \& Liu, Z. (2011). Modeling and analysis of the multiperiod effects of social relationship on supply chain networks. European Journal of Operational Research, 214(1), 39-52. https://doi.org/10.1016/j.ejor.2011.03.044.

Dacin, M. T., Ventresca, M. J., \& Beal, B. D. (1999). The embeddedness of organizations: dialogue \& directions. Journal of Management, 25(3), 317-356. http://dx.doi.org/10.1177/014920639902500304.

Dhanaraj, C., Lyles, M. A., Steensma, H. K., \& Tihanyi, L. (2004). Managing tacit and explicit knowledge transfer in 1JVs: the role of relational embeddedness and the impact on performance. Journal of International Business Studies, 35(5), 428-442. http://dx.doi. org/10.1057/palgrave.jibs.8400098.

Fonseca, J. J. S. (2002). Metodologia da pesquisa científica. Fortaleza: UEC.

Freeman, L. C. (1979). Centrality in social networks: conceptual clarification. Social Networks, 1(3), 215-239. http://dx.doi.org/10.1016/03788733(78)90021-7.

Fusco, J. P. A. (2005). Redes produtivas e cadeias de fornecimento. São Paulo: Arte \& Ciência.

Galbraith, J. R. (1997). Projetando a organização inovadora. In K. Starkey (Ed.), Como as organizações aprendem: relatos do sucesso das grandes empresas (pp. 190- 218). São Paulo: Futura.

Gil, A. C. (2008). Métodos e técnicas de pesquisa social (6. ed.). São Paulo: Atlas. 
Gilsing, V. A., \& Duysters, G. M. (2008). Understanding novelty creation in exploration networks-Structural and relational embeddedness jointly considered. Technovation, 28(10), 693-708. http://dx.doi.org/10.1016/j.technovation.2008.03.004.

Gobbo Junior, J. A., \& Vasconcellos, M. A. (2008). Proposal of a framework for the analysis of the innovation process in networks. In POMS Annual Conference (pp. 1633-1647). Tokyo: Gakushin University.

Gobbo, S. C. 0. (2010). Uma análise do embeddedness na formação de valor em redes de empresas: um exemplo de aplicação em uma rede do setor metal-mecânico (Dissertação de mestrado). Bauru: Universidade Estadual Paulista.

Gonçalves, J. E. L. (2000). As empresas são Grandes Coleções de Processos. Revista de Administração de Empresas, 40(1), 6-19. http:// dx.doi.org/10.1590/S0034-75902000000100002.

Gonzalez, G., Claro, D., \& Palmatier, R. (2014). Synergistic effects of relationship managers's social networks on sales performance. Journal of Marketing, 78(1), 76-94. http://dx.doi.org/10.1509/jm.11.0431.

Grandori, A., \& Soda, G. (1995). Inter-firm networks: antecedents, mechanisms and forms. Organization Studies, 16(2), 183-215. http:// dx.doi.org/10.1177/017084069501600201.

Granovetter, M. (1985). Economic action and social structure: the problem of embeddedness. American Journal of Sociology, 91(3), 481-510. http://dx.doi.org/10.1086/228311.

Granovetter, M. (1992). Problems of explanation in economic sociology. In N. Nohria \& R. G. Eccles (Eds.), Networks and organizations: structure, form, and action. Boston: Harvard Business School Press.

Granovetter, M. (2005). The impact of social structure on economic outcomes. The Journal of Economic Perspectives, 19(1), 33-50. http://dx.doi.org/10.1257/0895330053147958.

Gulati, R. (1998). Alliances and networks. Strategic Management Journal, 19(4), 293-317. http://dx.doi.org/10.1002/(SICl)10970266(199804) 19:4<293::AID-SMJ982>3.0.CO;2-M.

Halinen, A., \& Törnroos, J. A. (1998). The role of embeddedness in the evolution of business networks. Scandinavian Journal of Management, 14(3), 187-205. http://dx.doi.org/10.1016/S0956-5221(98)80009-2.

Hallikas, J., Karvonen, l., Pulkkinen, U., Virolainen, V., \& Tuominen, M. (2004). Risk management processes in supplier networks. International Journal of Production Economics, 90(1), 47-58. http://dx.doi.org/10.1016/j.jpe.2004.02.007.

Handfield, R., Krause, D., Scannell, T., \& Monckza, R. (2000). Avoid the pitfalls in supplier development. Sloan Management Review, 41(2), 37-49.

Hess, M. (2004). Spacial relationships? Towards a reconceptualization of embeddedness. Progress in Human Geography, 28(2), 165-186. http://dx.doi.org/10.1191/0309132504ph479oa.

Hoang, H., \& Antoncic, B. (2003). Network-based research in entrepreneurship: a critical review. Journal of Business Venturing, 18(2), 165-187. http://dx.doi.org/10.1016/S0883-9026(02)00081-2.

Jericó, M. C., Peres, A. M., \& Kurcgant, P. (2008). Estrutura organizacional do serviço de enfermagem: reflexões sobre a influência do poder e da cultura organizacional. Revista da Escola de Enfermagem da U S P., 42(3), 569-577. http://dx.doi.org/10.1590/S008062342008000300022 . PMid:18856127.

Johnson, T. (2010). Nos Bastidores da Wikipédia Lusófona: percalços e conquistas de um projeto de escrita coletiva on-line. Rio de Janeiro: E-papers.

Khodabandehloo, A. (2014). Networking for regional development: a case study. EuroMed Journal of Business, 9(2), 149-163. http:// dx.doi.org/10.1108/EMJB-10-2013-0045.

Khoja, F., Adams, J., \& Kauffman, R. (2010). A temporal model of vertical relationships. Journal of Business-To-Business Marketing, 17(3), 279-307. http://dx.doi.org/10.1080/10517120903465368.

Kilduff, M., \& Tsai, W. (2007). Social networks and organizations. London: Sage Publications.

Kim, D. Y. (2014). Understanding supplier structural embeddedness: a social network perspective. Journal of Operations Management, 32(5), 219-231. http://dx.doi.org/10.1016/j.jom.2014.03.005.

Kim, Y., Choi, T. Y., Yan, T., \& Dooley, K. (2011). Structural investigation of supply networks: a social network analysis approach. Journal of Operations Management, 29(3), 194-211. https://doi.org/10.1016/j.jom.2010.11.001.

Kirchherr, W. (1992). Kolmogorov complexity and random graphs. Information Processing Letters, 41(3), 125-130. http://dx.doi. org/10.1016/0020-0190(92)90040-3.

Koufteros, X., Vickery, S. K., \& Dröge, C. (2012). The effects of strategic supplier selection on buyer competitive performance in matched domains: does supplier integration mediate the relationships? The Journal of Supply Chain Management, 48(2), 93-115. http:// dx.doi.org/10.1111/j.1745-493X.2012.03263.x.

Lechner, C., Frankenberger, K., \& Floyd, S. W. (2010). Task contingencies in the curvilinear relationships between intergroup networks and initiative performance. Academy of Management Journal, 53(4), 865-889. http://dx.doi.org/10.5465/amj.2010.52814620.

Li, E., Liao, C., \& Yen, H. (2013). Co-authorship networks and research impact: a social capital perspective. Research Policy, 42(9), 1515-1530. http://dx.doi.org/10.1016/j.respol.2013.06.012.

Liao, J., \& Welsch, H. (2005). Roles of social capital in venture creation: key dimensions and research implications. Journal of Small Business Management, 43(4), 345-362. http://dx.doi.org/10.1111/j.1540-627X.2005.00141.x.

Lin, J. L., Fang, S. C., Fang, S. R., \& Tsai, F. S. (2009). Network embeddedness and technology transfer performance in R\&D consortia in Taiwan. Technovation, 29(11), 763-774. http://dx.doi.org/10.1016/j.technovation.2009.05.001.

Lopes, F. D., \& Baldi, M. (2009). Redes como perspectiva de análise e como estrutura de governança: uma análise das diferentes contribuições. Revista de Administração Pública, 43(5), 1007-1035. http://dx.doi.org/10.1590/S0034-76122009000500003.

Marques, B. (2015). Colaborar para vencer: gerir parcerias nos seguros. Porto: Vida Económica.

Mckenna, R. (1992). Marketing de relacionamento: estratégias bem sucedidas para a era do cliente. Rio de Janeiro: Campus.

Michelon, G. A. (2015). Centralidade ponderada por potencial aplicada à replicação de dados em redes ad hoc móveis (Tese de doutorado). Curitiba: Pontifícia Universidade Católica do Paraná.

Miguel, P. A. C. (2007). Estudo de caso na engenharia de produção: estruturação e recomendações para sua condução. Produção, 17(1), 216-229. http://dx.doi.org/10.1590/S0103-65132007000100015. 
Millington, A., Eberhardt, M., \& Wilkinson, B. (2006). Supplier performance and selection in China. International Journal of Operations \& Production Management, 26(2), 185-201. http://dx.doi.org/10.1108/01443570610641666.

Moran, P. (2005). Structural vs. relational embeddedness: social capital and managerial performance. Strategic Management Journal, 26(12), 129-1151. http://dx.doi.org/10.1002/smj.486.

Morrison, A., \& Rabellotti, R. (2009). Knowledge and information networks in an Italian wine cluster. European Planning Studies, 1777), 983-1006. http://dx.doi.org/10.1080/09654310902949265.

Mote, J. E. (2005). R\&D ecology: using 2-mode network analysis to explore complexity in R\&D environments. Journal of Engineering and Technology Management, 22(1-2), 93-111. http://dx.doi.org/10.1016/j.jengtecman.2004.11.004.

Muniady, R., Al Mamun, A., Mohamad, M. R., Permarupan, P. Y., \& Zainol, N. R. B. (2015). The effect of cognitive and relational social capital on structural social capital and micro-enterprise performance. Sage Open, 5(4), 1-9. https://doi.org/10.1177/2158244015611187.

Nahapiet, J., \& Ghoshal, S. (1998). Social capital, intellectual capital, and the organizational advantage. Academy of Management Review, 23(2), 242-266. http://dx.doi.org/10.5465/amr.1998.533225.

Nelson, R. (2001). On the shape of verbal networks in organizations. Organization Studies, 22(5), 797-823. http://dx.doi. org/ $10.1177 / 0170840601225003$.

Oliver, A. L., \& Ebers, M. (1998). Networking network studies: an analysis of conceptual configuration in the study of inter-organizational relationships. Organization Studies, 19(4), 549-583. http://dx.doi.org/10.1177/017084069801900402.

Parkhe, A., Wasserman, S., \& Ralston, D. A. (2006). New frontiers in network theory development. Academy of Management Review, 31(3), 560-568. http://dx.doi.org/10.5465/amr.2006.21318917.

Pineyrua, D. G. F., Ferreira, M. P., \& Biancolino, C. A. (2016). Aplicação da Análise de Redes Sociais em uma Instituição Pública: identificação de redes informais e grau de centralidade. Revista Espacios, 37(30), 12.

Polanyi, K. (1944). The great transformation: the political and economic origins of our time. New York: Farrar \& Rinehart.

Polidoro Junior, F., Ahuja, G., \& Mitchell, W. (2011). When the social structure overshadows competitive incentives: the effects of network embeddedness on joint venture dissolution. Academy of Management Journal, 54(1), 203-223. http://dx.doi.org/10.5465/ amj.2011.59215088.

Prodanov, C. C., \& Freitas, E. C. (2013). Metodologia do trabalho científico: métodos e técnicas da pesquisa e do trabalho acadêmico (2. ed.). Novo Hamburgo: Feevale.

Provan, K. G., Fish, A., \& Sydow, J. (2007). Interorganizational Networks at the network level: a review of the empirical literature on whole networks. Journal of Management, 33(3), 479-516. http://dx.doi.org/10.1177/0149206307302554.

Rao, H., Davis, G. F., \& Ward, A. (2000). Embeddedness, social identity, and mobility: why firms leave the NASDAQ and join the New York stock exchange. Administrative Science Quarterly, 45(2), 268-292. http://dx.doi.org/10.2307/2667072.

Rost, K. (2011). The strength of strong ties in the creation of innovation. Research Policy, 4O(4), 588-604. http://dx.doi.org/10.1016/j. respol.2010.12.001.

Rowley, T., Behrens, D., \& Krackhardt, D. (2000). Redundant governance structures: an analysis of structural and relational embeddedness in the steel and semiconductor industries. Strategic Management Journal, 21(3), 369-386. https://doi.org/10.1002/(SICl)10970266(200003)21:3<369::AID-SMJ93>3.0.C0;2-M

Sacomano Neto, M. (2004). Redes: difusão do conhecimento e controle - um estudo de caso na indústria brasileira de caminhões (Tese de doutorado). Universidade Federal de São Carlos, São Carlos.

Sacomano Neto, M., \& Truzzi, O. M. S. (2009). Posicionamento estrutural e relacional em redes de empresas: uma análise do consórcio modular da indústria automobilística. Gestão e Produção, 16(4), 598-611. http://dx.doi.org/10.1590/S0104-530X2009000400009.

Silva, G., \& Heber, F. (2013). Ecologia Organizacional e Teoria de Redes: uma análise contemporânea da formação de APLS. Em pauta: Revista da Gestão e Regionalidade da USCS, 30(88), 34-48.

Simsek, Z., Lubatkin, M. H., \& Floyd, S. W. (2003). Inter-firm networks and entrepreneurial behavior: a structural embeddedness perspective. Journal of Management, 29(3), 427-442. http://dx.doi.org/10.1016/S0149-2063(03)00018-7.

Sluzki, C. E. (1997). A rede social na prática sistêmica (Trad. Claudia Berliner). São Paulo: Casa do Psicólogo.

Swedberg, R. (2004). Sociologia econômica: hoje e amanhã. Sociologia econômica? Hoje e amanhã, 16(2), 7-34.

Tiwana, A. (2008). Do bridging ties complement strong ties? An empirical examination of alliance ambidexterity. Strategic Management Journal, 29(3), 251-272. http://dx.doi.org/10.1002/smj.666.

Tsai, W. (2001). Knowledge transfer in intraorganizational networks: effects of network position and absorptive capacity on business unit innovation and performance. Academy of Management Journal, 44(5), 996-1004.

Tsai, W., \& Ghoshal, S. (1998). Social capital and value creation: the role of intrafirm networks. Academy of Management Journal, 41(4), 464-476.

Uzzi, B. (1996). The sources and consequences of embeddedness for the economic performance of organizations: the network effect. American Sociological Review, 61(4), 674-698. http://dx.doi.org/10.2307/2096399.

Van Eck, P. S., Jager, W., \& Leeflang, P. S. H. (2011). Opinion leaders role in innovation diffusion: a simulation study. Journal of Product Innovation Management, 28(2), 187-203. http://dx.doi.org/10.1111/j.1540-5885.2011.00791.x.

Vasconcelos, G. M. R., \& Oliveira, J. L. (2012). Imersão social e institucional e capacidades: o setor calçadista de Nova Serrena. Revista de Administração de Empresas, 52(5), 531-545.

Wasserman, S., \& Faust, K. (1994). Social network analysis. Cambridge: Cambridge University Press. http://dx.doi.org/10.1017/ CB09780511815478.

Weick, K. E. (1995). Sensemaking in organizations. Thousand Oaks: SAGE.

Yang, H., Lin, Z., \& Peng, M. W. (2011). Behind acquisitions of alliance partners: exploratory learning and network embeddedness. Academy of Management Journal, 54(5), 1069-1080. http://dx.doi.org/10.5465/amj.2007.0767.

Yin, R. K. (2001). Estudo de caso: planejamento e métodos (2. ed., Trad. Daniel Grassi). Porto Alegre: Bookman.

Zukin, S., \& DiMaggio, P. (1994). Structures of capital: the social organization of economy. Cambridge: Cambridge University Press. 